Research Article

\title{
SYMBOLIC INTERACTION OF MIGRANT WOMEN IN PONTANG DISTRICT, BANTEN PROVINCE
}

\author{
Rahmi Mulyasih*, Ahmad Sihabudin, Fahruddin Faiz \\ Communication Studies, Sahid University, Jakarta
}

Article history:

Submission 09 November 2021

Revised 10 November 2021

Accepted 11 November 2021

*Corresponding author:

E-mail:

bikiya16@gmail.com

\begin{abstract}
Migrant women are a phenomenon that describes a change in the position of husband and wife in the life of Indonesian society in general. This study aims to explore the interactions that occur between migrant women and their families and communities which then lead to symbols that are interpreted differently by migrant women, families and communities. The research method used in this study uses an ethnomethodological method, which in this research method reflects behavior and tries to understand or interpret someone and others. The results of the study illustrate that there are symbols that are interpreted as meaning the success of migrant women with big and nice houses, jewelry worn and vehicles. These symbols then create a new culture or different interactions between migrant women, both with their families and communities.
\end{abstract}

Keywords: Migrant Women, Symbolic Interaction, Social Interaction

\section{Introduction}

Migrant women are a social phenomenon of a cultural change that occurs in Indonesian society. This cultural change arises from the existence, shifting roles between husband and wife and changing positions between wife and husband positions. In general, the ideal of a woman lies in her character who is gentle, obedient and does not argue with her husband. So according to Raharjo (1995) the ideal role of a wife is when she can manage the household, support her husband's career, be obedient to her husband and be able to educate her children. Meanwhile, men are described as "allknowing" and become role models for women, and can think rationally and aggressively. Therefore, the ideal role for men as heads of families is when they can be responsible by earning a living for their families, as protectors, and being able to protect their families. (Putri \& Lestari, 2015)

The role of the husband in the family which is ideally described in the majority of Indonesian families in general, is not found in the description of the family of migrant women. In migrant women's families, domestic roles such as cooking, cleaning the house and taking care of the family which are usually the domain of a wife are taken over by the husband. Meanwhile, the wife changes her role towards the public, by working as a migrant woman abroad to earn a living for her family.

Changes in roles and positions between husband and wife in migrant women's families then lead to social interaction, which gives rise to different symbols, norms and values

\section{How to cite:}

Mulyasih, R., Sihabudin, A., \& Faiz, F. (2021). Symbolic Interaction of Migrant Women in Pontang District, Banten Province. Indonesian Journal of Social Science Research, 2(2), 104 - 109. doi: 10.11594/ijssr.02.02.07 
between migrant women and the surrounding environment such as family and society. The return of migrant women to their hometowns brings a new culture in the surrounding community, for example from the style and appearance that reflects the unusual modern culture of the surrounding community, not to mention the presence of other symbols of success such as renovating houses, buying vehicles and investing in rice fields and fields which then become indicators of progress in economic and social status in the community.

The symbol of success contained in the phenomenon of migrant women when viewed from the symbolic interactionism proposed by Blumer (1973) emphasizes human action which is based on three premises, namely meaning is formed from objects that originate from human actions. This meaning begins with the social interaction that occurs between migrant women and the surrounding environment. It is this social interaction that not only shapes meaning but also changes and creates an interpretation of the symbols of migrant women's social interactions. (Alver \& Caglar, 2015)

The symbols of success for migrant women give their own meaning to the surrounding community, which makes the profession as a migrant woman a special attraction, so it is not surprising that in Indonesia, many areas have emerged which are referred to as TKW (Women Worker) villages, because the majority of women are women. in this area work as migrant women. One of them is in Pontang subdistrict, which is one of the sub-districts in Serang district, Banten province, as one of the largest supplying areas for women migrants abroad. The phenomenon of migrant women developing in Pontang District has existed since 1970 to 1980 . At first only a few Pontang women worked abroad as migrant women, but with the symbols displayed by migrant women, it became a special attraction for the community to follow in the footsteps of being a migrant woman.

The study of "symbolic interactions of migrant women in Pontang District", is a study of the interactions that occur between an individual and the community. Where, individuals are seen as actors who can interpret, assess, define and act from social interactions carried out with the surrounding community. According to Palomo (1993), society is defined as a number of individuals who are connected by interaction. The interaction that occurs then becomes permanent, so the relationship becomes very important to do, because society as an event that can overcome individuals or social dualism, in this case individuals can be involved with one another so that social interaction occurs. (Anggaunitakiranantika, 2017)

Social interactions that occur between migrant women and the surrounding environment in Pontang District not only form new symbols of interaction among the community but are also able to change the mindset of the community, which assumes that the role and position of women are only as domestic actors, changing the role of their position in the community. the public sector by becoming a migrant woman.

\section{Theoretical Framework Family Communication}

Family is the beginning, children learn about life from parents as their children's first madrasa. So it is necessary to have an effective communication interaction between parents and children to create a harmonious relationship between parents and children. The normal life that usually exists in Indonesian families consisting of a father, a mother and children living in a house, cannot be found in the families of migrant women, this is because the mother requires them to work abroad for a long period of time. . So that the children are then cared for by the father or the closest family from the father's side or the mother's side.

From this, family communication becomes very necessary for a family. According to Rae Sedwig (1985), family communication is an organization that uses words, gestures, voice intonation, actions to create image expectations , express feelings and share mutual understanding (Sumakul, 2015).

The understanding of family communication above provides an illustration that the words, body language, voice, and behavior of each interaction between family members reflect the expression that radiates both in the form of verbal communication and non-verbal 
communication through communication symbols caught in every communication interaction. which is conducted.

\section{Symbolic Interaction}

Symbolic Interaction Theory, was first introduced by George Herbert Mead who was heavily influenced by the thoughts of Whilhem Wundt. According to Morissan (2013) Symbolic Interaction views that social life is basically "human interaction using symbols", so that symbolic interaction is interested in how humans use symbols that represent what is intended when communicating with others, and the influence arising from the interpretation of symbols on the behavior of the parties involved in social interaction. (Sitandung et al., 2018).

Therefore, the perspective of symbolic interaction is more directed to human behavior which is basically an interpretation of the world around it. So according to Mulyana (2007) humans act only based on their interpretation of the objects around them, so it is not surprising that the phrase "situation definition" reality is in "the eye that sees and if humans define the real situation then the real situation and its consequences are often associated with with symbolic interactions. (Nahria \& Laili, 2018)

\section{The Meaning of Migrant Women}

Interactions carried out by migrant women with people in the surrounding environment, both when they have not become migrant women and after becoming migrant women give rise to communication symbols both verbally and non-verbally which are then interpreted by the actions that migrant women apply in their daily lives. -day.

Stock of knowledge has an influence in the formation of meaning from each individual which will lead to developments between the scope of space, time and culture. According to Cangara (2009) states that there are two needs when humans carry out the communication process, namely the need to maintain their survival and the need to adapt to the surrounding environment. Therefore, when viewed contextually, social communication is human communication where the communication is intended to create a harmonious relationship between one human being and another human being. (Kadir et al., 2020)

From the description of meaning put forward by Cangara, it can be concluded that the meaning that exists within each individual is a human communication process that is based on forming a " harmonious relationship " so that in essence meaning is a "social phenomenon contained in the concept of communication which consists of interpretation and individual understanding that is mutually agreed upon with the surrounding community.

\section{Methods}

The study, "Symbolic Interaction of Migrant Women in Pontang District", is included in the ethnomethodology research method where ethnomethodology looks at the division of meaning that occurs between each individual in everyday life. so that in this case ethnomethodology looks at the social reality constructed by social actors. (Farias et al., 2021) in this study the social actors are migrant women who carry out social interactions with the surrounding environment such as family and community members, which in turn creates the existence of social reality in interpreting the existence of symbols of interaction such as the success of migrant women.

While the research approach uses a qualitative approach, where the qualitative approach is more directed to studies that focus on reality that has practical interpretation. The data sources used are divided into two, primary and secondary. For the data in the primary category, the researcher used in-depth interviews with migrant women, husbands and the community, while the secondary data was obtained by researchers through documentation, bibliography and observation.

\section{Results and Discussion}

Migrant women's interactions with the surrounding environment produce an interpretation that ultimately limits the actions of each individual. The concept in symbolic interaction was identified by Emeriti, Jerome Manis and Bernard Meltzer (1978) into seven principles summarized in Blumer's thinking, including human interaction which is characterized by the presence of symbols that are interpreted 
differently, individuals become more human when interacting with other people. In addition, society can be understood if it is in the interactions that occur within each member of the community, which in the end individuals will be active when they can form behavior, awareness and thoughts that involve interactions not only with themselves but also with others, therefore individuals will construct their behavior in everyday life. (Bloor \& Wood, 2011)

The seven basic principles contained in symbolic interactions provide an illustration of the symbolic interaction that occurs between migrant women and their environment, which consists of symbols in the form of physical such as buildings and objects as well as symbols in the form of non-physical such as the style of dress or the language used. The physical symbols that exist in migrant women, mostly in the form of luxury houses which are usually part of one of the motives of migrant women to go to work abroad.

Pontang was once a rural and slum area, so that it became one of the underdeveloped areas in Serang Regency. So it is not surprising, when you find Pontang in the past as an area that is still inhabited by people who still live in houses that are relatively far from proper and road infrastructure facilities are still not good. This is because, Pontang is an area that only has marine resources and there is still a lack of job opportunities, so the people work as fishermen or sell processed foods such as "bontot", which is a typical food from the Pontang area.

This situation then encourages the community to rise from the backwardness and poverty they face, one of which is by sending Pontang women to work abroad. From the phenomenon of many migrant women who leave and return to their hometowns, in the end it brings a cultural change, one of which is a symbol of success by successfully renovating houses towards livable and luxurious houses.

Luxurious houses are an indicator of the success of migrant women working abroad, this symbol is not only a symbol of success for migrant women, but also a symbol of the husband's success in managing the finances given by his wife while working abroad. Therefore, renovating houses or building houses is a top priority for migrant women working abroad, until finally Pontang has become a relatively developed area not only with many luxurious and beautiful houses, the result of migrant women working abroad but also facilities and infrastructure. road infrastructure and relatively readily available public facilities such as money changers or money transfer and receipt services.

Big and nice houses, we find more around Kampung Dollar while for houses in other villages in Pontang, usually only renovated to make it more habitable and permanent, because in the past the houses in Pontang were still houses. room made of thatch. Dollar Village, which is still included in the Pontang District, is a relatively more developed village than other villages in Pontang District. This is because, in Dollar Village, there are many luxurious and beautiful houses that have resulted from Pontang women becoming migrant women. In addition, the characteristics of migrant women, in terms of lifestyle are also more varied, such as in the style of dress and behavior, this is because the migrant women in Dollar Village work with various countries of origin such as Thailand, Hong Kong. While the average migrant women in Pontang, the majority work in Arabia, due to the similarity of religion adopted by the people of Pontang.

Homes for some Pontang migrant women are not only a place to live, but also as a prestige symbol to be judged as a success in working abroad. This is as expressed by Tjahjono in the book Santosa (2000), which reveals that the house for some people is not only a place to live, but the house is also a symbol for its owner, so that the position of the house as a reflection of the personality and lives of its inhabitants (Tondi \& Iryani, 2018).

With this, the house has become an important thing and the main goal for some migrant women from Pontang, to make the money from working abroad to renovate houses that are more livable and even tend to be luxurious and nice. Because in the end the house which is a symbol of success becomes part of the community's measuring value in seeing the success of migrant women in working abroad as well as the success of the husbands of migrant women 
in managing the finances generated by migrant women while working abroad.

Another physical symbol that is an indicator of the success of migrant women is vehicles such as motorbikes. This motorbike has become a "dream" for migrant women and their families to have, because Pontang is an area that still has difficulties in the field of public transportation, therefore "motorcycles" are an alternative to make it easier for migrant women's families to carry out daily activities such as going to school and going to school. work everyday.

In addition to symbols that are displayed in physical form to indicate the "success" of migrant women, there are other physical objects that are more directed towards appearance, namely "gold" jewelry. Usually, the purchase of gold is a priority for migrant women who do not have families. There are differences in lifestyle patterns that can be seen from migrant women who are married and those who are not married, usually migrant women who are married, housing is the main priority to be repaired from the results of working abroad. Meanwhile, for migrant women who are not married, the results of working as migrant women are spent to fulfill their lifestyle by walking or fulfilling their desires and buying "jewelry" in the form of gold .

Gold, is part of the symbol of "wealth" for some Indonesian people, especially Banten. So don't be surprised if during the Eid celebration, people will go to a jewelry store to buy gold to be worn on the holiday, so that family and relatives will see the jewelry worn and judge that the individual's life has been in a relatively high economic strata. .

The use of jewelry is also often done by migrant women who have just returned from working abroad. because this is part of the characteristics or signs that are often obtained from migrant women who have just returned to their hometowns. The use of this jewelry is deliberately done by migrant women, as part of the symbol of "success and success", working abroad. From the phenomenon, the use of jewelry worn by migrant women raises the motivation of Pontang women who have not worked abroad to become migrant women, because of the attractiveness of "jewelry" worn by migrant women and views that working as a migrant woman means that they will have a lot of "money" so you can buy jewelry.

Renovation of houses, purchase of vehicles and jewelry to fulfill the "dreams" and lifestyles of migrant women and their families, resulting in the money earned from working abroad running out and migrant women will be faced with financial difficulties because the demands to meet the necessities of life continue while there is no other income. other than the money earned from working abroad. in the end, migrant women will think about returning to work abroad and leaving their families back. This is the reason why migrant women can work for decades, and there are even some migrant women who eventually do not return to their hometowns because they get married or die while working abroad.

Therefore, it is necessary to have the participation of every element in society, in order to provide training on skills for migrant women and their families. As well as the view that being a migrant woman is not a solution to the problems in life they face, because after all, there are many problems that arise when Pontang women decide to become migrant women by working abroad, especially the problem of child growth and development, because they still need the role of "mother". " in his life.

In addition to physical symbols, which are displayed by migrant women, there are also non-physical symbols depicted by migrant women, one of which is "clothing". In terms of dress, it turns out that migrant women in Pontang are not affected by culture at work. For example, migrant women who work in Saudi Arabia will always wear an "abaya" or "veil" when they return to their hometown. However, this is not done by migrant women from Pontang, because usually Pontang women who have just returned from abroad will wear the clothes they used to wear before becoming a migrant woman. But for some young migrant women, there are changes in their clothes, especially migrant women from Kampung Dollar.

This is because, migrant women who come from Kampung Dollar work to several countries abroad such as Hong Kong, Taiwan, Arab and so on. As a result, the atmosphere and 
characteristics of the community are different from other villages in Pontang District. This includes the way of dressing, in general, migrant women in Pontang wear headscarves and women's clothing as usual. In contrast to Pontang women from Kampung Dollar, who are relatively more "slang" than Pontang women from other villages. Because most of the migrant women in Dollar Village, there are some who dye their hair, wear clothes that lead to modern elements, which can give the assumption to people who see that these migrant women have just returned from abroad.

Clothing is a symbol of cultural manifestation so that it can communicate messages nonverbally and be interpreted by an individual. This is because clothing is part of the aesthetic reflection of symbols in society, such as the things contained in social values and customs that describe a person's social status and economic status.

The communication process carried out by migrant women with the surrounding environment is carried out using everyday language, where the majority of migrant women use the Javanese Serang or Jaseng language as well as the Sundanese language. However, if the interaction is carried out with other migrant women in the same country of employment, sometimes the migrant woman uses the foreign language in which she works.

\section{Conclusion}

Migrant women are a representation of the existence of gender equality between men and women, where women are no longer the second class after men. The role of the man as the head of the family can be replaced by the wife who in fact is the party who is always in the domestic sphere. This shift in roles gives rise to symbols of communication interactions created from the communication process carried out by migrant women with the surrounding environment, both symbols based on verbal and nonverbal communication. However, the symbols of interaction that exist can then be interpreted differently by both migrant women and their environment, such as the meaning of a nice and big house, vehicle or style of dress.

\section{References}

Alver, F., \& Caglar, S. (2015). The impact of symbolic interactionism on research studies about communication science. International Journal of Arts and Sciences, 08(07), 479-484. http://universitypublications.net/ijas/0807/pdf/ V5G165.pdf

Anggaunitakiranantika, A. (2017). Interaksi Buruh Migran Perempuan Sebagai Kekuatan Modal Sosial. Jurnal Sosiologi Pendidikan Humanis, 2(1), 33-40. https://doi.org/10.17977/um021v2i12017p033

Bloor, M., \& Wood, F. (2011). Symbolic Interactionism. Keywords in Qualitative Methods, 160-163. https://doi.org/10.4135/9781849209403.n52

Farias, M. L., Sousa Júnior, J. H. de, Moura, B. M., SouzaLeão, A. L. M. de, \& Farias, S. A. de. (2021). Etnometodologia como Abordagem Metodológica para os Estudos de Consumer Culture Theory. Marketing \& Tourism Review, 6(1), 1-25. https://doi.org/10.29149/mtr.v6i1.6308

Kadir, B., Bahfiarti, T., \& Farid, M. (2020). Social Communication of Addewatang Putta Sereng Ritual in Bone Regency. Jurnal Ilmu Budaya, 8(2), 208215. https://doi.org/10.34050/jib.v8i2.10985

Nahria, N., \& Laili, I. (2018). Studi Etnometodologi Pelanggaran Komunikasi (Communication Breaching) Di Pasar Tradisional Youtefakota Jayapura. Jurnal Common, 2(2). https://doi.org/10.34010/common.v2i2.1188

Putri, D. P. K., \& Lestari, S. (2015). Pembagian Peran Dalam Rumah Tangga. Jurnal Penelitian Humaniora, 16(1), 72-85.

Sitandung, Y., Cangara, H., \& Maria, J. (2018). Penggunaan Simbol-Simbol Komunikasi Nonverbal Dalam Menghindari Kecelakaan Transportasi Laut Kabupaten Biak Numfor Provinsi Papua. The Using of Nonverbal Communication Symbols in Avoiding Sea Transportation Accidents in the Circle of Anak Perahu in Padaido. 7(1), 117-123.

Sumakul, B. J. (2015). journal "Acta Diurna" Volume IV. No. 4. $\operatorname{IV}(4)$.

Tondi, M. L., \& Iryani, S. Y. (2018). Nilai Dan Makna Kearifan Lokal Rumah Tradisional Limas Palembang Sebagai Kriteria Masyarakat Melayu. Langkau Betang: Jurnal Arsitektur, 5(1), 15. https://doi.org/10.26418/lantang.v5i1.25383 